www.jmscr.igmpublication.org Impact Factor 5.244

Index Copernicus Value: 5.88 ISSN (e)-2347-176x ISSN (p) 2455-0450 crossref DOI:_http://dx.doi.org/10.18535/jmscr/v4i6.03

\title{
Cystic Lymphangioma - Report of Atypical Case in Adult Female
}

\author{
Authors \\ Sagar R. Ambre, Mayank Chakarborty, Shahaji Chavan, Anuradha Dyanmote, \\ Mahendra Bendre, Vinayak Khirsagar, Prashant Male
}

\begin{abstract}
Lymphangioma are uncommon lesion of lymphatic channels that are often present at birth and diagnosed mostly (90\%) before the age of two years. lymphangiomas are mainly seen in neck. We report a case of cystic lymphangioma in 45 years female patient which was successfully resected with a postoperative favorable outcome.
\end{abstract}

KEYWORD- cystic lymphangioma, adult, surgery.

\section{INTRODUCTION}

Lymphangiomas are uncommon lesion of lymphatic channels lymphangiomas are mainly seen in neck, axilla, and mediastium ${ }^{(1)}$.cystic lymphangiomas (90\%) seen before the age of two years. The lesion constitute $6 \%$ of all benign tumor of childhood ${ }^{(2)}$. Lymhangiomas occurs rarely in adult and few cases are noted till now ${ }^{(2,}$ 3). trauma or infection are responsible for their pathogenesis ${ }^{(4,5)}$.

\section{CASE REPORT}

45 year female patient came to the OPD with complaints of a swelling in the right supraclavicular region since 40 years. $8 * 6 \mathrm{~cm}$ swelling visible in right supraclavicular region in the posterior triangle of the neck. There was no fever no regional lymphadenopathy. Lab investigations were as follows-Hb-11.4gm\%,TLC$4600 /$ cumm of blood, polymorphs- $60 \%$, lymphocytes-30\%, ESR-18mm/hour, Random blood sugar- $88 \mathrm{mg} / \mathrm{dl}$,liver and renal profile WNL, chest X-ray PA view was within normal limit. Tattoo marks were noted over the swelling, swelling was soft, non tender, transilluminated and mildly compressible. Skin over swelling is pincheble, swelling

Swelling was mobile in all directions.USG neck and MRI neck-well defined thin walled unilocular thin walled oval shaped altered signal intensity lesion with its extent 5.4/4.6/4.8. swelling in right supraclavicular region causing a bulge of overlying skin situated anterior to trapizeus muscle lateral to sternocledomastoid lower border posterior to middle third clavicle superior to inferior belly of omohyoid muscle. Intraoperative finding was cystic swelling which was excised and sent for HPE. corrugated drain were kept in situ in the cavity. Procedure was uneventful HPE report suggestive of endothelial lined lymphatic spaces are seen intervening fibrous tissue and lymphoid aggregates. Finding suggestive of cystic lymphangioma. 


\section{DISCUSSION}

lymphangiomas are rare and occurs mainly in childhood $^{(2)}$. cystic lymphangioma or cystic hygroma is a low flow vascular malformation. where lymph sacs are separated from venous drange system $^{(6)}$. lymphangiomas has been classified into three groups-Lymphangioma simplex, Cavernous lymphangioma, Cystic hygroma $^{(7,8)}$. Cystic lymphangioma appears in the neck, axilla, and rest in mediastinum, retroperitonium, pelvis and chest wall ${ }^{(1)}$.patient with lymphangioma of the neck and mediastinum are usually asymptomatic but they may present chest pain, cough,dyspnea, dysphagia, vascular compression syndromes ${ }^{(9,10)}$. The diagnosis of cystic lymphangiomas either with USG and CT as well as with MRI is to be done ${ }^{(9,10)}$. FNAC may be helpful in exclusion of malignancy ${ }^{(11)}$.complete surgical resection is usually the treatment of choice for cystic lymphangioma ${ }^{(11)}$.other type of treatment have seen proposed as adjuvant such as radiotherapy and injection of sclerosant agents but they are controversial ${ }^{(12)}$.meticulous surgical excision is treatment of choice however a few local recurrences, fistula malformation or injection have been reported ${ }^{(1)}$. adult lesions have lower recurrence rates after complete excision ${ }^{(13)}$.

\section{CONCLUSION}

Lymphangioma is benign tumor provided that in our case tumour is completely resected. A good prognosis is achieved and there is no complication. The treatment of choice is complete surgical removal, with lesion recurrence in 21$88 \%$.This study is worth reporting due to rareness of cystic lymphangioma in adult.

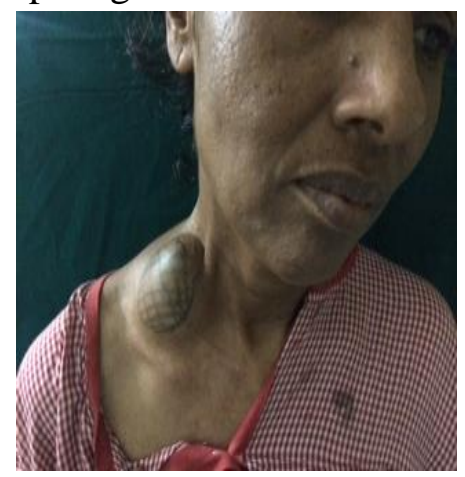

PREOPERATIVE
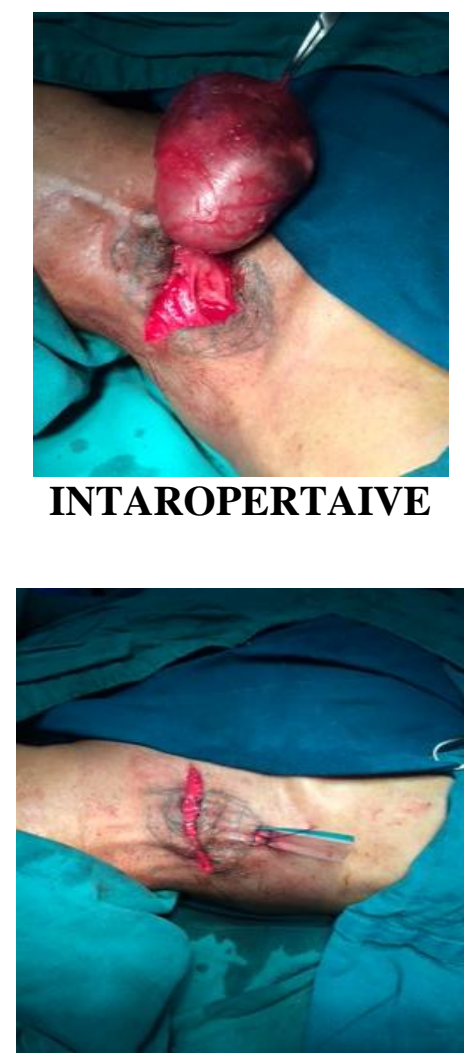

POSTOPERTIVE

\section{REFERENCES}

1. Bossert T, Gumment JF, Mohr FW, giant cystic lymphangioma of the mediastinum, Eur. J Cardiothorac surg.2002:21:340.

2. Pia F, Aluffip,Olina M, cystic lymphangioma in the head and neck region, Acta otorhinolaryngoTtal 19;87-90

3. Wiggs WJ Jr, Sismanis A (1994) cystic hygroma in the adult two case report. Otolaryngol Head neck surg 110;239-241

4. Gleason TJ, Yah WT, Tali ET,et al (1993) traumatic cystic lymphangioma in an adult, Ann otol rhinol laryngol 120;564566

5. Aneeshkumar MK, Kale S, Kabhani M, et al (2005) cystic lymphangioma in adult; can truma be the trigger? Eur Arch Otol Rhinol Laryngol 262;335-337

6. Mohammadi A,Ghasemi-rad ,Abassi F, Asymptomatic lymphangioma involving the spleen and mediastinum in adult, Med Ultrson 2013;15;154-6

7. Brown CR,Peiman HM,Rosenow EC, Gloviezki DM, Divertie MB. Intrathoracic 
lymphangioma.mayo clin Proc 1986; 61;882-92

8. Oshikiri T,Morikawa T, Jinushi E, Kawankani Y, Katoh $\mathrm{H}$, Five case of lymphangioma of mediastinum in adult, ANN thorac cardiac surg 2001;721;130-5

9. Correia FM, Seabra B, Rego A, etal cystic lymphangioma of the mediastinum,J Bras Pneumol 2008;34;182-4

10. Shaffer K,Rosado-de-Christenson ML,Partz EF jr, et al thoracic lymphangioma in adults ; ct an mr imaging features AJR Am J REoentgenol 1994;162;283-9

11. Curran AJ, Malik N, Mc share D, etal (1996) surgical management of cystic lymphangiomas in adults. J Larymgol otol 110;586-589

12. Ardenghy M, Miura Y, Kovach R, Hochberg J, cystic hygroma of the chest wall; a rare condition, Ann plast surg 1996;37;211-3

13. Karka PD ,Spencer MG , Lee M, et al (2005) cervical cystic hygroma; an acquired idiopathic late presentation. J laryangol otol 119;561-563. 